\title{
Assessing the Influences of Mother Tongue on English Language During Group Discussion: Bachira Secondary School in Grade Ten (10) in Focus
}

\author{
Handebo Hankore, lecturer \\ Kebri Dehar University, College of Social Science, Department of English Language and Literature
}

\begin{abstract}
The main aim of this study was to assess influence of mother tongue on English Language during group discussion. The informants of the study were in students and teachers at Bachira secondary school. The researcher selected 25 students who were randomly selected and two English language teachers who were selected purposively. The researcher used questionnaire and interview in order to collect relevant data from the respondents. The researcher used statistic and thematic analysis of data in order to analyze the collected data from the respondents. The result of the study indicated that the lack of confident and lack of knowledge of the target language where the most influential factors for student to use their mother tongue in group discussion at Bachira secondary school. Thus, to minimize these problems it is recommended that teachers should strive to improve students' confidence in group discussion.
\end{abstract}

Keywords: English, Mother tongue, target language

DOI: $10.7176 /$ RHSS/11-5-04

Publication date:March $31^{\text {st }} 2021$

\section{Introduction}

1. Background of the Study

It is obvious that English is international Language which is spoken all over the world. It may be influence by mother tongue of the nation. In our country, there are different ethnic groups with their own mother tongue Language. It obvious they use their mother tongue language in their daily conversations. Observed that in Ethiopia context, class room is the only place for learning foreign language. There are no other environments for the students to be exposed of the target language.

Researcher should focus on how group discussion plays a role in language classes in order to help learners. Improve their speaking skill and the factors contributing for the interference of mother tongue during group discussion. Mother tongue interference during group discussion is one of the hindrances for the improvement of foreign language. Therefore, that in order to reduce it, identifying the factors that contribution for the interference of mother tongue is important. Different scholars explained different things regarding group work in the class and the factors that affect group work.

According to kohm(1986), students in small group should perceive to gather that each member is responsible and dependent on all. Effective language learning cannot be succeed unless the group is led in language pattern. Students know that group work is power and through which rely on one another.

According to Bacham, et al (1990), students learn best when they are actively involved in the process of discussion. Beside this researcher reported that regardless of the subject matter, student working in small group tend to learn more of. What is thought and retained larger than when the same content is presented in other structural formats. Students who work in collaborative group also appear more satisfied with other classes.

In addition, cooper, etal(1990) said that group of 4 or 5 members work best and large group decrease each members opportunity to participate actively, less the skill full the group member are the smaller the group should be to mean that smaller group is acceptable and needed in discussion. On the other hand, the Russian psychologist Lev Vygotsky (1962) said that the first language is both cultural tool, which induct students in to the shared knowledge and understanding of their society, and a physiological tool, which extends their learning and development.

Using the first language in interference of the second language, class room creates difference that the student can manage language one independently and without support of its member, but to compare his/her general knowledge to the group students, he/she should choose group discussion rather than independence because group discussion is the significant one to share knowledge of the group and to have more knowledge about the subject.

This shows that having group with large number of students and the inference of that mother tongue language could affect the active participation of member in the group. These effects or impacts are positive and negative impacts. Positive impacts are to develop mother tongue where as its negative impact are students are limited in mother tongue and highly affected factors that contribute for the inference of mother tongue having group discussion. 
The students of at Bachira secondary school follow the process of group discussion. As researcher observed informally, the students use their mother tongue to solve what they find is difficult to understand. This interference has its own problem on the students learning of the issue. That is why the researcher to assess the potential factors which contribute for the students use of mother tongue during group discussion.

According to David Adebayo Oluwole(2008), the research done in junior secondary certificate examination in western Nigeria on assessing the impact of mother tongue on students achievement in English language. It depends on the students parents and home environment explain the influence of mother tongue on English language. This is not only enough to say the influence of mother tongue for students English language achievement. But the students also used mother tongue language while they discuss with in group. This is why the researcher initiated to assess factors that contribute for usage of mother tongue during group discussion.

Mother tongue interference during group discussion is one of hindrance for the improvement target language. In the researchers' experience, the teaching learning process is being converted to mother language and English language is not adopted. So that in order to reduce the problem it identify the factor that contribute for the interference of mother tongue important

\section{Methodology}

A mixed research design method was followed. . The researcher chose only grade ten Bachira students because before choosing the researcher frequently observed those students while they have been discussing by employing their mother tongue. In grade ten, there are 135 students and 5 English teachers. From the students, there researcher selected only 25 students who are purposively selected , and five teachers. Then, the researcher distributed questionnaires for students, and conducted interview with teachers. Finally, thematic and statistic methods of data was takes place

\section{Discussion on findings}

\subsection{Responses of the students Questionnaires}

The students at Bachira secondary school in grade 10 almost have their own different mother tongue. But as it can be deduced from the discussion they mainly used Amharic and Tambarissa as a medium according to the result of the questionnaire distributed, the subject where asked the language they use during group discussion. The response could be seen as in the following table.

Table 1 student's response on the language that used mostly in group discussion

\begin{tabular}{|l|l|l|}
\hline Alternative & Respondents in number & Respondents in percentage \\
\hline English & 8 & $32 \%$ \\
\hline Tambarissa & 11 & $44 \%$ \\
\hline Amharic & 6 & $24 \%$ \\
\hline Other & - & - \\
\hline Total & 25 & 100 \\
\hline
\end{tabular}

As in the table $32 \%$ of the subjects replied that they used Amharic, 24\% (6) responded that they used English and the rest of the subjects 44\% (11) responded that they used Tambarissa language as large of communication and understanding in group discussion in the class room. This indicates that the majority of the subject in this finding used their own language so it is common to used mother tongue during discussion in the Grade 10 classroom.

Table 2. Do you used to your mother tongue during group discussion?

\begin{tabular}{|l|l|l|}
\hline Alternative & Respondent in number & Respondent in percent \\
\hline Yes & 17 & $68 \%$ \\
\hline No & 8 & $32 \%$ \\
\hline Total & 25 & $100 \%$ \\
\hline
\end{tabular}

According to the above table 2:/ $68 \%$ / of the subject replied that they used to mother tongue during group discussion. on the other hand $8 / 32 \% /$ of the subjects replied that they do not used in mother tongue. The subjects their mother tongue during group discussion the reason that they used in their mother tongue is that they face difficulty to express their ideas easily. When they learn English language, they also said that it is easy to express their ideas using their mother tongue and exchange information with their group members. They also reported that they used in their mother tongue to avoid luck of confidence and filling of anxiety that could be observed during the discussion in the target language.

Table: 3 Do you think group discussion supports language learner?

\begin{tabular}{|l|l|l|}
\hline Alternative & Respondent in number & Respondent in percent \\
\hline Yes & 17 & $68 \%$ \\
\hline No & 8 & $32 \%$ \\
\hline Total & 25 & $100 \%$ \\
\hline
\end{tabular}


Table 4 indicates $68 \%$ of the subjects believed that group discussion support the development of the language learning whereas as $32 \%$ that are only eight students did not believe on the significance of the group discussion in class. The researcher mentioned by the respondents who support the importance of group discussion in language learning are group discussion promote communication, increase the ability of pronunciation skill which make them good introduce with their group members, in addition they could not develop languages skill without discussion or practicing in group. It can be deduced that group discussion encourage English Language learner.

Table 4; Do you think using mother tongue during group discussion has negative effect on your language learning? (Negative impact of using mother tongue in English Language Learning)

\begin{tabular}{|l|l|l|}
\hline Alternative & Respondent in number & Respondent in percent \\
\hline Yes & 19 & $76 \%$ \\
\hline No & 6 & $24 \%$ \\
\hline Total & 25 & $100 \%$ \\
\hline
\end{tabular}

Table 4; indicates that $76 \%$ of the respondents support that it has effect on their learning process where as the $24 \%$ of the respondents did not believe on the effect of mother tongue during group discussion. As stated in the table mother tongue highly affect group discussion English class room. Therefore, it is possible to conclude that mother tongue has negative effect on the target language.

Table 5 : students attitude towards the using of mother tongue during group discussion

\begin{tabular}{|l|l|l|}
\hline Alternative & Respondent in number & Respondent in percent \\
\hline Positive & 10 & $40 \%$ \\
\hline Negative & 15 & $60 \%$ \\
\hline Total & 25 & $100 \%$ \\
\hline
\end{tabular}

As the table indicates $40 \%[10]$ of the subjects have positive attitude towards their mother tongue at the time of Kebridehar secondary school discussion, 75\%[9] subjects have negative attitude towards the used of mother tongue during group discussion. As it is possible to see from the above response the majority of students have negative attitude towards used of mother tongue during group discussion. So it can suppose that mother tongue interference have negative influence on improvement of target language.

Table 6: The factor that affect students to use in mother tongue during their group- discussion.

\begin{tabular}{|l|l|l|}
\hline Alternative & Respondent in number & Respondent in percent \\
\hline $\begin{array}{l}\text { lack of knowledge the target } \\
\text { language }\end{array}$ & 11 & $44 \%$ \\
\hline Shyness & 4 & $16 \%$ \\
\hline Lack of confidence & 10 & $30 \%$ \\
\hline Total & 25 & $100 \%$ \\
\hline
\end{tabular}

In the table $7: 44 \%$ (11)of the subjects replied that lack of knowledge of target language is one factor to used to their mother tongue. The respondents thoroughly responded that the ability to know only one languages monolingual) force you to speak your mother tongue. People who are multi signal can speak different language. Therefore, this can be the major factor affecting not to use the target language. Students who have lack of knowledge target language are un able or unwilling to take part in activities in English's rather they used their mother tongue. As result, this interference of mother tongue affects the target language (English language). 16\% (4) students replied that shyness is the factor used to their mother tongue. The subject for their explained that shyness is one commune factor interference of mother tongue to other language during group discussions. Most of them afraid to speak, because they feel sham when they make mistake. $30 \%$ (10) responded that lack of confidence is the reason used to mother tongue during group discussion they replied that they are very worry of using the target language. So that they don't have full confidence used to it. Most of the students are worried of grammar. Do you to this reason they mix their mother tongue with foreign language during the group discussion.8\% (1) of the students responded that or all the above factors can affect students used their mother tongue during group discussion. Therefore from the above response of the students one can easily reduce that lack of knowledge of the target language, target language is one of the major factors used to their mother tongue during group discussion. In addition, shyness and lack of confidence to speak English language are also other factors used to their mother tongue. Those factors hinder the improvement of the students' target language. 


\subsection{Questionnaires for teachers}

Table 7: Do you think that using mother tongue group discussion helps the students to improve their English skill

\begin{tabular}{|l|l|l|}
\hline Alternative & Respondent in number & Respondent in percent \\
\hline Yes & 1 & $20 \%$ \\
\hline No & 4 & $80 \%$ \\
\hline Total & 5 & $100 \%$ \\
\hline
\end{tabular}

The teachers whereas asked to give their response about whether mother tongue helps student during group discussion or not. According their response $20 \%$ of the subject responded that using mother tongue by the student during group discussion improves their English language speaking skill and $80 \%$ responded that using mother tongue does not help students to improve their English language skill. From this the researcher can inferred that mother tongue does not help students to improve their English language skill. Thus, it is possible to say using mother tongue during group discussion discourages improvement of English language skills.

Table 8: Do you motivate your students to speech mother tongue in group discussion?

\begin{tabular}{|l|l|l|}
\hline Alternative & Respondent in number & Respondent in percent \\
\hline Yes & 5 & $100 \%$ \\
\hline No & - & $0 \%$ \\
\hline Total & 3 & $100 \%$ \\
\hline
\end{tabular}

As it can be observed from table, all respondents $100 \%(5)$ of the subject replied that they motivate their students in-group discussion Therefore, from this it is possible to conclude that teachers motivate their students to involve in group discussion.

Table 9: Do you think that group work is important for English language learning?

\begin{tabular}{|l|l|l|}
\hline Alternative & Respondent in number & Respondent in percent \\
\hline Yes & 5 & $100 \%$ \\
\hline No & - & - \\
\hline Total & 5 & $100 \%$ \\
\hline
\end{tabular}

Table 9: The above table indicates that all of the respondents $100 \%$ believe that group discussion is very important for English language learning. Beside the respondents were asked how much group discussion is important. Accordingly, all of them said that it is very important for promoting English language learning.

Table :10 what mechanism do you used to evaluate the students?

\begin{tabular}{|l|l|l|l|}
\hline No & Respondent of the teachers & $\begin{array}{l}\text { Respondent } \\
\text { number }\end{array}$ & $\begin{array}{l}\text { Respondent } \\
\text { percent }\end{array}$ \\
\hline 1 & Evaluate them by asking comprehension questions & 1 & $33 \%$ \\
\hline 2 & $\begin{array}{l}\text { I evaluate them by asking questions and letting them to } \\
\text { present }\end{array}$ & 4 & $67 \%$ \\
\hline & Total & 5 & $100 \%$ \\
\hline
\end{tabular}

As we can see from table $\mathbf{1 0 : 3 3 \%}$ of the teacher said that' he evaluate the students by asking comprehension question's on other hand $67 \%$ of the respondents said that they evaluate their students by acting different question and by letting them to present their assignment in front of their classmates.

Table 11: do you think that all members of the students get equal chance to participate in group discussion?

\begin{tabular}{|l|l|l|}
\hline Alternative & Respondent in number & Respondent in percent \\
\hline Yes & 4 & $80 \%$ \\
\hline No & 1 & $20 \%$ \\
\hline Total & 5 & $100 \%$ \\
\hline
\end{tabular}

Table 11 indicates that $80 \%$ (4) of the subjects said that the students get equal chance to participate ingroup discussion $20 \%$ (1) of the students said, the students do not get equal chance in-group discussion. There for from this it is logical to generalize that majority of the teacher give equal chance to students to participate ingroup discussion.

Table:12 Do students used their mother tongue during group discussion?

\begin{tabular}{|l|l|l|}
\hline Alternative & Respondent in number & Respondent in percent \\
\hline Yes & 5 & $100 \%$ \\
\hline No & - & - \\
\hline Total & 5 & $100 \%$ \\
\hline
\end{tabular}

According to the table $12100 \%$ of the subject replied that they used to their mother tongue during group discussion. The reasons for them to used in their mother tongue are that they face difficulty to express their idea easily when they used to the target language and they have negative attitude towards English language. 


\section{Conclusion and Recommendation \\ Conclusion}

Most of the teachers said that students used to their mother tongue in the target language and they added that's mother tongue is not good to improve students speaking skill. Similarly, the finding of the study indicated that lack of knowledge of target language, shyness, and lack of confidence are factors that contribute for the usage of mother tongue in-group discussion. Generally, the finding shows that success and development in the speaking is determined by student's interest and a great deal of teachers who guide the students.

\section{RECOMMENDATION}

Based on the above conclusions of the study, the researcher forwards the following suggestions:

- Even though students face different challenges to express their idea, they should using to the target language so as to improve their speaking skill.

- Students who feel shy also should improve in the way that they should practice outside of class with their friends and hopefully they could improve their behavior and even their speaking skill.

- $\quad$-Students who feel lack of confidence should not be undermined by themselves and even by their group members. But to be confident, students should also practice outside. Practicing is good so as to improve their speaking skill and to become confident. This helps them to speak and practice in class without any fear.

- The teacher should motivate for the students who used to English language during group discussion.

- Teachers should work hard to improve the students' knowledge, confidence and their attitude. Therefore, students will avoid all the problems and can be good communicators in their group discussion.

\section{Reference}

Barcam et al (1990). The Routledge Encyclopedia of Second Language acquisition.

Cambridge University

Cooper et al (1990). Cognitive Theory as anAid for Instructional design .Cambridge University

Khom (1986). Model of Communicative Competences .Cambridge university

Levugotsky (1962). Thought and Language .Cambridge University: MIT press 